\title{
ХАРЧУВАННЯ МОЛОДІ УКРАЇНИ В УМОВАХ СУЧАСНОСТІ
}

\author{
О. В. Оксютенко
}

\author{
Київський міський медичний коледж
}

У статті висвітлено проблеми раціонального харчування, з якими стикається молодь України, та методи, які допомагають вирішенню цієї актуальної проблеми.

\section{THE POWER OF YOUTH OF UKRAINE IN MODERN CONDITIONS}

\author{
O. V. Oksytenko
}

\section{Kyiv Municipal Medical College}

The article highlights the problems of nutrition faced by the youth of Ukraine, and the methods that help solve this pressing issue.

Вступ. Збереження та зміцнення здоров'я і формування здорового способу життя молодого покоління нині $\epsilon$ актуальною проблемою загальнодержавного масштабу. Міцне здоров'я і висока здатність адаптації до дії факторів навколишнього середовища є одними з найважливіших умов формування особистісних якостей людини. Харчування посідає значне місце у формуванні здорового способу життя кожної людини, зокрема і молоді. Перевантаження, байдуже ставлення до свого здоров'я, відсутність гарних умов життя та доброякісних продуктів, постійні порушення здорового способу життя і режиму харчування, а інколи нестача коштів та інші чинники - усе це у комплексі завдає великої шкоди здоров'ю молоді.

Основна частина. Харчування - це процес надходження, перетравлення та засвоєння інгредієнтів, необхідних організмові для відшкодування його енерговитрат, побудови та оновлення тканин і регуляції функцій організму. Правильний «обмін речовин» між природою та живим організмом дуже важливий.

На даний час стан захворюваності та смертності населення визначають такі патології, як хвороби серцево-судинної системи і онкологічні захворювання. Зростає кількість хвороб, які пов'язують із надмірною масою тіла: цукровий діабет II типу, атеросклероз, гормональні порушення. Збільшується частка захворювань, в розвитку яких домінують алергічні процеси. Одним із патогенетичних факторів розвитку наведених захворювань $\in$ нераціональне харчування [1]. (c) О. В. Оксютенко, 2016
Згідно з дослідженням, проведеним Державним науково-дослідницьким центром із проблем гігієни харчування, всі основні групи продуктів харчування з високою біологічною цінністю (м'ясо та м'ясопродукти, риба та рибопродукти, молоко та молокопродукти, фрукти, овочі та ін.) споживаються істотно менше, ніж це потрібно згідно з сьогоднішніми дієтичними рекомендаціями [2].

Як демонструють дані соціологічного дослідження «Ставлення молоді України до здорового способу життя» харчування української молоді відзначається значним споживанням страв з картоплі, зокрема смаженої, світлого хліба та солодощів, макаронних виробів, копченої ковбаси тощо. щонайменше один раз на день $28 \%$ підлітків споживають солодкі газовані напої, 30 \% - шоколадні вироби, 34 \% - здобні вироби та тістечка, $14 \%$ - чіпси та сухарики, майже 8 \% споживають смажені пиріжки та іншу «вуличну їжу», i, як наслідок - зростання захворювань, в основі яких порушення вуглеводного і ліпідного обмінів, атеросклероз, ішемічна хвороба серця, гіпертонічна хвороба, цукровий діабет, і як не прикро, з кожним роком ці хвороби омолоджуються [2].

щодо режиму харчування - він є важливим складником раціонального харчування. Режим передбачає регулярне споживання їжі у певні проміжки часу, а також розподіл добового раціону за енергоцінністю протягом дня. Дотримання режиму харчування забезпечує ефективну роботу системи травлення, нормальне засвоєння їжі та правильний обмін ре- 
човин. А щодо української молоді, то вона схильна до споживання високалорійної їжі, зокрема пізно ввечері, і 18 \% - це роблять у закладах громадського харчування різного типу. І як наслідок такого нераціонального харчування розвиваються захворювання шлунка, кишечника тощо (гастрит, виразкова хвороба шлунка, панкреатит, коліт тощо). За рекомендацією вчених, для запобігання хворобливих станів кожній людині потрібно дотримуватися таких принципів харчування [3]:

1. Енергетична цінність раціону харчування повинна відповідати енергетичним витратам організму.

2. Хімічний склад їжі має відповідати фізіологічним потребам організму у поживних речовинах (кожен прийом їжі має бути максимально збалансованим).

3. Раціони харчування повинні складатися з різноманітних продуктів переважно рослинного, а не тваринного походження.

4. Оптимальний режим харчування, що забезпечує регулярність (4-5 разів на день) надходження їжі та включення психофізіологічного механізму травлення [3].

Наступна проблема, з якою стикається молодь України - недостатність харчування.

Недостатність харчування - одна з форм порушення харчування. Недостатнє харчування може бути результатом неадекватного споживання поживних речовин, мальабсорбції, порушеного метаболізму, втрати нутрієнтів при проносі або при збільшенні потреби в їжі.

Енергія, яка витрачається організмом, повинна постійно компенсуватися їжею, інакше організм змушений поповнювати витрачене за рахунок своїх внутрішніх ресурсів. У результаті маса тіла буде зменшуватися, але при цьому:

- призупиниться зростання;

- ослабнуть захисні сили організму;

- буде наростати слабкість, швидка психічна та фізична втомлюваність, відчуття холоду;

- постійним буде відчуття голоду, спраги;

- зменшиться фізична сила;

- відчуватиметься запаморочення;

- поступово настане виснаження, схуднення;

- з'являться порушення статевої системи;

- буде спостерігатися блідість, кволість, зморшкуватість, сухість шкіри, сухість, ламкість, випадання волосся тощо [4].

Усі ці потенційні наслідки необхідно враховувати при проведенні довготривалих виснажливих дієт, якими нерозумно захоплюється наша молодь (приблизно 6 \%), доводячи себе до захворювань шлунково-кишкового тракту, розладу ендокринної системи, дистрофії із серйозними порушеннями в організмі. Зменшувати надмірну масу тіла потрібно поступово, залучаючи до цього процесу цілий комплекс заходів, а саме:

- по-перше, необхідно звернутись до лікаря;

- по-друге, варто збільшити рівень фізичної активності;

- по-третє, переглянути свої харчові звички та змінити їх на більш раціональні [5].

Доведено, що фізіологічним $\in$ зменшення маси тіла не більше, ніж на 3-4 кг за місяць до показника нормальної маси. У випадку такого неквапливого схуднення організм поступово адаптується до нових зрушень, відсутній фактор «стресу». Навпаки, якщо людина, а особливо молодий організм, швидко позбавляється зайвої маси (більше 3 кг на місяць), організм переживає значний стрес, напружуються всі механізми життєдіяльності, може статися порушення цих механізмів, наслідком чого буде розчарування після припинення дієти людина знову набирає масу, причому навіть більшу, ніж втратила [6].

В умовах складних екологічних та соціальноекономічних умов, зміни умов сільського господарства і виробництва, виникнення джерел нової харчової сировини і технологій їі переробки в державі гостро постали питання щодо забезпечення населення здоровим харчуванням. Лише 26 \% молоді України звертають увагу на склад продукції, яку вони купують, майже половина робить це зрідка, а 23 \% ніколи. Однак більшість молодих людей виступає за заборону генно-модифікованої продукції (ГМО), 15 \% це ті, кому байдуже або хто не бачить у цьому нічого шкідливого [2].

Суперечки про шкідливість чи нешкідливість модифікованої їжі йдуть і, напевно, будуть тривати ще багато років. У свою чергу, фахівці-противники гмО наводять дані досліджень, які підтверджують негативний вплив ГМО як на людину, так і в цілому на навколишнє середовище. У численних дослідженнях йдеться про ту відчутну шкоду, якої завдають ГМО-продукти здоров'ю молоді. Зокрема, можливе виникнення алергічних реакцій, пригнічення імунної системи. Можуть бути виявлені різні розлади обміну речовин. Відомо, що в Швеції, де трансгенні продукти заборонені до реалізації, тільки 7 \% населення хворіють на алергію, тоді як в США, де така ̈̈жа в широкому 
доступі (і навіть не має спеціального маркування) частка алергіків - 70,5\% [2].

Деякі дослідники стверджують, що у результаті тривалого споживання продуктів, що містять ГМО, може розвинутися стійкість патогенної мікрофлори людини до антибіотиків, яка, в свою чергу, призведе до виникнення труднощів при лікуванні різних захворювань, аж до неможливості їх лікування. ГМОпродукти можуть викликати надалі різні мутації в організмі людини, а також призвести до онкологічних захворювань [7].

Світ поділено на два табори - захисників і противників впровадження ГМО-продуктів у масове виробництво. Але все ж наслідки поширення ГМо не може передбачити ніхто. Тому дуже тішить нинішня ситуація, коли вчені, звичайні споживачі, громадські організації ретельніше стежать за тим, які продукти харчування пропонують нам виробники. І особлива увага приділяється генетичній чистоті продуктів. Наприклад, в супермаркетах країн Західної Європи для

\section{ЛІТЕРАТУРА}

1. Підаєв А. В. Панорама охорони здоров'я України / А. В. Підаєв, О. Ф. Возіанов. - К. : Здоров'я, 2005. - 302 с.

2. Романова Н. Ф. Молодь за здоровий спосіб життя / Н. Ф. Романова. - К. : Міністерство України у справах сім'ї, молоді та спорту, 2010. - 75 с.

3. Олексієнко Я. І. Харчування та його вплив на здоров'я людини : навчально-методичний посібник / Я. І. Олексієнко, В. А. Шахматова, О. П. Верещагіна. - К. : ПП Чабаненко Ю. А., 2014. - 87 с.

4. Гулий І. С. Основи валеології / І. С. Гулий, Г. О. Сімахіна. - К. : НУХТ, 2009. - 220 с. товарів, що містять ГМО, виділяють окремі полиці, в пресі публікують списки компаній, що використовують у виробництві ГМО-інгредієнти.

У нашій країні вирішенню проблеми правильного адекватного харчування можуть допомогти:

- усвідомлення необхідності зміни своїх харчових звичок;

- дотримання вимог раціонального харчування;

- загальнодержавні заходи, спрямовані на захист здоров'я населення, зокрема заборона у виробництві ГМО-інгредієнтів, та пропаганду і створення умов для раціонального харчування.

Висновок. Молодь нашої держави має хибні уявлення щодо здорового харчування. Щоденний раціон молодої людини є далеким від того, яким має бути здорове харчування, але, як не прикро, значна частина молоді не вважає його шкідливим і навіть схвалює, хоча структура $є$ нераціональною і загрозливою для здоров'я не тільки молодого покоління, а й навіть для всієї нації.

5. Бондар Т. В. Формування здорового способу життя молоді / Т. В. Бондар, О. Г. Карпенко. - К. : Український інститут соціальних досліджень, 2005. - 118 с.

6. Яременко О. О. Формування здорового способу життя молоді: стратегія розвитку українського суспільства / О. О. Яременко. - К. : Державний інститут проблем сім'ї та молоді, 2009. - Ч. 1. - 90 с.

7. Харчування і здоров'я: критерії раціонального харчування [Електронний ресурс]. - Режим доступу : http:// www.studopedia.com.ua/ 